\title{
THE ROLE OF FUNCTIONAL AND TERRITORIAL EVOLUTION IN THE GENESIS OF RĂDĂUȚI'S INTERNAL STRUCTURE
}

DOI: http://dx.doi.org/10.18509/GBP.2019.58

UDC: 908(498)

\author{
Lăzărescu Luminița-Mirela \\ Efros Vasile \\ "Ștefan cel Mare" University of Suceava, Faculty of History and Geography, \\ Departament of Geography, Romania
}

\begin{abstract}
The town`s complexity as a geographical space is given by the basic characteristics of the components of the human habitat (natural, human and social-economical) which dictate the internal organization in different stages of its evolution. The purpose of the research is to reconstruct the stages of the territorial and functional evolution of Rădăuţi and to describe the contribution to the configuration of the actual internal structure of the settlement. In this paper, the process of internal structuring is analyzed as a continuous process, from the documentary attestation of the settlement (14th century) until today. The main results of the study will be: cartographic representation of territorial evolution and current functional zoning; explaining the specificity of the current urban morphostructure by correlating it with its generating factors; presenting the main functional changes that took place during the internal structuring process of the city. Highlighting the most significant quantitative and qualitative changes that contributed to the city's internal structuring process was based on analyzing, interpretation and processing bibliographic, cartographic and statistical data.
\end{abstract}

Keywords: territorial and functional evolution, functional area, urban morphostructure

\section{INTRODUCTION}

The city is a system with a certain content, structure and spatial organization, being a concrete manifestation of the effect of the interaction of demographic, social and economic spaces projected on physical space over time [1]. As a result of a complex and long-lasting process of economic and social development, the city can be characterized as an open system that responds both to the needs of the interior and to the outside. The internal structuring of the city and the formation of the functional areas is the result of relations established over time between its components (territory, population, human activities). In order to meet the human and material needs of the human settlement, the city's territory has, over time, been differentiated, in accordance with the favorability of space for certain activities. Within it, there have been individualized, over time, spaces with different utilities and functions. Initially, in the first stages of development of the city, several social-economical activities took place on the same territory, later, as it developed and extended, functions began to individualise and give specific to certain territories within it [2], leading to the formation of functional areas and directing its location to the internal structure of the city. The developement of Rădăuți has forced old structures to adapt to new requirements. Some more powerful changes have remained in the internal structure of Rădăuți, while others have been eliminated in ulterior stages. The analysis of territorial and functional evolution offers us the possibility of understanding 
the actual internal structure and identifying the necessary steps to ensure the coherence of urban space.

\section{STUDY AREA}

The studied area is represented by Rădăuţi town, the third largest city in Suceava County, which covers an area of 32,30 square km. [3]

The town is located approximately in the center of Rădăuţi depression, within the Suceava Plateau, the mathematical position of the city is defined by the coordinates $25^{0} 35$ east longitude and $47^{0} 51$ northern latitude.

Rădăuţi is limited to the east by Dorneşti commune, to the west of Marginea, north of Frătăuţi, and to the south by Volovăţ.

\section{METHODOLOGY}

We investigated the process of territorial extension of the settlement for a period of 245 years (1773-2018) by observing, analyzing and processing olds and recents maps and satellite images of the settlement. For this analysis eight maps were selected: digitized cadastral maps of Habsburg Empire: the maps sheet of First Military Survey (1773-1776) scale 1:2.880, the map of Galicia and Bucovina (1861-1864) - Second Military Survey, scale 1:25.000; the map of Third Military Survey (1910), scale 1:75.000 (all availables at www.mapire.eu); The Military Firing Plan, Rădăuți sheet, 1951, scale 1:20.000; The military topography map, 1984-1985, Rădăuți sheet, scale:1:25.000; the ortophotoplans anf aerofotogrames of Rădăuți for 2005 and 2012 (available online at www.geoportal.gov.ro) and satellite images provided by Google Earth platform for 2018. On each selected map, the boundaries of urban space were plotted, later, using the ArcGIS program this maps were georeferenced and overlapped and the areas of territorial growth are then highlighted. At the same time, the surface of the settlement was measured on each map, the data obtained indicating a continuous territorial growth, but with a differentiated rhythm. The cartographic information was correlated with the information provided by the statistical data series on the numerical growth of the population, the builtup area of the city etc., taken from the bibliographic sources (for older periods), from the County Statistical Office or from the site of National Institute of Statistics of Romania. The field observation of the architecture of buildings and their usefulness, the materials on these platforms (plans, topographical maps and aerial views) provided us rich and reliable information on the shape and structure (morphology) of the urban settlement at certain times, the aspect of the street tram (settlement texture) the expansion of urban space and the developmental trends of the city. The information obtained from the bibliographic sources, from direct observation in the field, from the cartographic materials related to the General Urban Project documentation (2010), was the basis for the mapping of the functional zoning map of Rădăuţi. The information was processed using the Arc Gis software.

\section{RESULTS AND DISSCUSIONS}

The current physiognomy of Rădăuţi town and the degree of urban planning have been imposed both by the characteristics of the environment and the anthropogenic intervention exercised on them over time. Information on the existence of the locality is provided both by the bibliographic sources and the first useful statistical and cartographic information about the area that appeared in the second half of the eighteenth century, with 
the annexation of Bucovina by the Habsburg Empire. The first documentary mention of Rădăuţi appeared in 1393, together with the village of Volovăţ, Rădăuţi being mentioned as Radomir's village [4], that is, belonging to Radomir's properties, from which, as some versions say, the name of the village would also be called. The fact that voivode Bogdan I (1359-1365), the founder of the Moldavian feudal state, chose Rădăuţi as the place of building the reigning church, the oldest stone church in Moldova, proves the existence of a demographic center already developed, stable, with a profound economic and social life. [5].

Dimitrie Cantemir briefly writes about the locality that would sooner or later turn to a radiant glow: "Radauti, a comer and chair of a bishop, is also placed on the Suceava River and Siret, where it hovers to the south." [6]

The territorial evolution of the locality was realized on the background of several historical contexts, each of them having a great impact on the later physiognomy and internal structure of the city. In the development process of the locality, two stages are distinguished: the one of rural development (14th century until the beginning of the 19th century) and the stage of urban development, which in turn included the fair stage (18191852 ) and the city phase (1852 - present). [7]

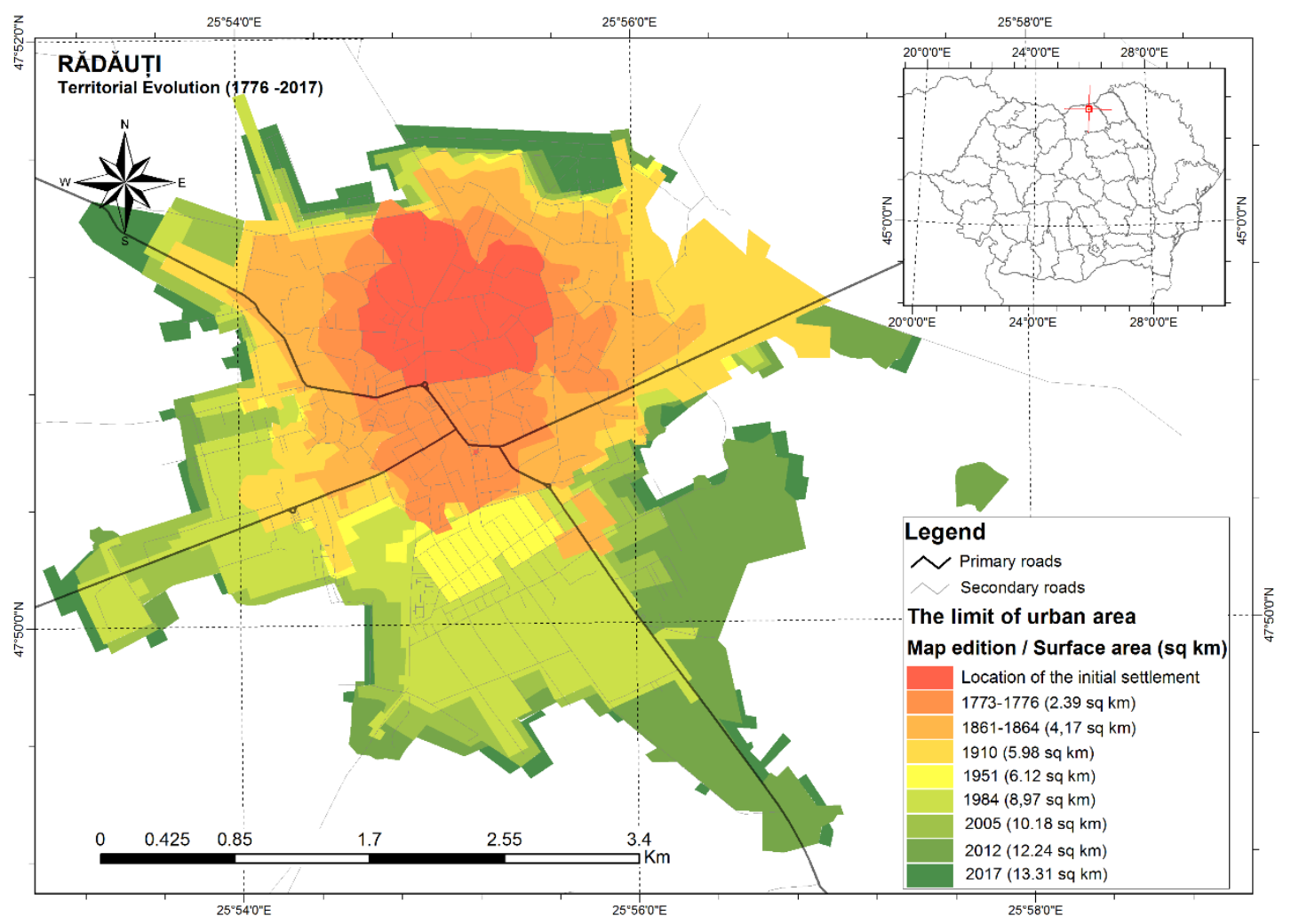

Figure 1. Rădăuți - Territorial evolution reconstituted on the basis of old cartographic documents and current satellite imagery

As can be seen on Fig 1., the first constructions from Rădăuţi (mostly dwellings) were located to the north of the actual settlement, where it was shaped, XIV-XVI, the original nucleus of the locality. In an attempt to capitalize on the dry land the population raised their homes on land located north and northeast of that nucleus. To the south of initial settlement were few constructions, the Bogdana Monastery and the related buildings being representative. Over time, as indicated by the austrians map between 1773-1880, between the original settlement and the monastery, several constructions emerged as a 
result of the establishment of groups of monastic workers (mainly represented by Gypsies), thus forming the first craft cores from Rădăuţi.

The extension of the locality to the south has long been stopped by the existence of marshy lands that occupy large spaces south of the settlement, fact also marked on the historical maps we have consulted. In the period immediately following the entry of Rădăuţi under the Habsburg occupation, important landscaping works began (the marsh land between from the settlement and the Monastery was drained, was stretching the sewerage of Topliţa, the arrangement of the roads and even some sidewalks, the extension of the built space etc.). "There were walled and cobbled roads, planted with large poplars on the far side which offered a good perspective of how the land, ruled by the local authorities and placed under army control, was stretching out. And from one end of the poplar row to the other, there were towering households with soldiers, stables and stone barns, thoughtful places of hard work of all kinds ... ."[8]

During the Habsburg occupation, the population of the locality grew on the basis of the establishment of a significant number of Germans and Jews here. This fact was reflected both in the social-economical development of the locality (Rădăuţi becomes a trade fair in 1819 and a town in 1852), as well as in its territorial extension. In this context, the city stands out as a distinct model of inter- and multiculturalism in which the way of life of the population here was influenced by the history of the place. Local culture and lifestyles have been enriched and modeled by the arrival of colonists, who have, over time, contributed to the city's development, as has happened in many other colonized cities and regions of our country.

The analysis of territorial evolution between 1861-1864 indicates the expansion of Rădăuţi to the south, on one side and the other side of the river Topliţa in the central part of the current city. From the end the 19th century until the beginning of the 20th century the map analysis indicates a densification of the space especially built in the central part, where the trade-craft and administrative nucleus is distinguished, which has preserved its position so far in the internal structure of the city. Old buildings are now incorporated into the historic center of the city, although their utility has changed over time (some of them still have upstairs housing, most of the ground floor being occupied by shops and offices).The land use within the settlement (residential and agricultural land) is preserved over time, contributing to the configuration of the city's current residential and agricultural areas. Also we notice that Rădăuţi, in that period, was already connected with the neighboring localities through a road system: the Suceava Road entered the locality through the southern part and continued with the Putna road that was coming from Rădăuţi through the northwest. Besides these roads, there were many paths that were coming out of Rădăuţi to Fratauţi, Volovăţ, Dorneşti and Satu-Mare, which the inhabitants or visitors used in their journeys. [9] Roads and paths, used from the $15^{\text {th }}$ century, to which others were added in time, contributed to the sketching of the street tram and the urban morphostructure that characterizes the city today. Thus, the geometric character of the main network, with rectangular arteries converged towards the locality and diverging to the outside (character inherited from the 16th-17th centuries), and the non-systematized aspect of the secondary road network, as a result of the spontaneous, undirected evolution of the locality in this period.

An important event that influenced the extension and internal structuring of the locality was the construction and putting into operation, in 1889, of Rădăuţi-Dorneşti railway. The use of the railway facilitated the transportation of raw materials from nearby areas to the city, which boosted the rise of factories and mills along the railway, contributed to the 
development of trade, crafts and transport. This led to the emergence of the first industrial concentrations of the city along the railway and led to an important territorial expansion of the locality in the east-west direction. The territorial expansion of this period may also be explained by the gradual detachment of the dwelling from the workplace, which produces a tendency to disperse in the peripheral area. [10]

The 1910-1950 period is characterized by a stagnation of the city's expansion, as a result of the consequences of the two world wars on the city. It is very important to emphasize that, since the beginning of the 20th century, ,the expansion of the neighborhoods has not occurred spontaneously, but by the division of the different properties". [11] The only area in which the city expanded during that period (the result of the 1922 agrarian reform) was the one between Liceului Street (later V.I. Lenin, now Bucovina Street) and Volovăţ Street was divided into lots [12], being transformed in a few years into a residential neighborhood dominated by individual dwellings and embedded in the city's internal structure.

The slowing of territorial growth during the two world wars is the result of economic stagnation, the reduction of demographic dynamism, the disappearance of immigration and destroying the built heritage of the cities. [13]

After the war, the population of Rădăuţi needed a long time to increase again, given the loss of the majority of the male population. It was only in the sixth decade of the 20th century that the population increased from 18.780 inhabitants in 1965 to 30.454 at the end of 1989. [14] This contributed to this increase also by the birth policy adopted by the socialist state at that time, but also by the migratory flows from the rural areas adjacent to the industrialized city. Increasing the volume of investment to expand the living space has resulted in an important process of territorial expansion of the city. Thus, in the southern and southwest part of the locality, the new town, characterized by a rectangular, system-based morphostructure, consisted of collective housing assemblies grouped in residential districts: Bogdan Vodă, Călăraşi, Stadium and Hurmuzachi (built between 1965 - 1970), the Hipodrom - Grănicer neighborhood, Mihai Viteazul and the Obor district (built between 1975 and 1980).

In the period after 1990, on the basis of demographic inertia, in the first phase, there was a slight increase in the number of the population, given by the still high birth rate and positive migratory growth. Territorial evolution had a slower pace and was achieved by thickening the inner space, especially in the northern half of the city, as a natural consequence of the evolution of an urban settlement, given that some individual dwellings have exceeded their use period, while others replaced them.

Table 1. Indicators reflecting population dynamics and housing stock for Radauti (2001-2011)

\begin{tabular}{|ccccccccccc|}
\hline INDICATORS & $\mathbf{2 0 0 1}$ & $\mathbf{2 0 0 2}$ & $\mathbf{2 0 0 3}$ & $\mathbf{2 0 0 4}$ & $\mathbf{2 0 0 5}$ & $\mathbf{2 0 0 6}$ & $\mathbf{2 0 0 8}$ & $\mathbf{2 0 0 9}$ & $\mathbf{2 0 1 0}$ & $\mathbf{2 0 1 1}$ \\
\hline $\begin{array}{c}\text { Stable } \\
\text { population total }\end{array}$ & 31.621 & 29.809 & 29.494 & 29.289 & 29.308 & 29.373 & 29.188 & 29.259 & 29.451 & 29.523 \\
\hline $\begin{array}{c}\text { Number of } \\
\text { dwellings }\end{array}$ & 10.663 & 10.695 & 10.744 & 10.838 & 10.894 & 11.016 & 11.239 & 11.442 & 11.592 & 11.705 \\
\hline
\end{tabular}

(Source: INS-BDL Data, Sheet of Rădăuţi, 2001-2011)

Between 2005-2012, the territorial expansion of the city was also achieved through territorial expansion to the south, southwest and south-east. The need to ensure comfort, privacy, living in quieter areas, away from noise and pollution has prompted largerincome residents to renounce collective houses in favor of individual dwellings and thus contribute to land transformation from the southern and southern outskirts and the eastern part of the city in residential areas dominated by single-family dwellings. 
Map analysis (Figure 1) shows a significant tentacular extension along the county road channel of communication that connects Rădăuţi de Suceava, this channel being the most important in terms of the streams of entry into the city, an important extension to the east by the capitalization of the agricultural land for residential buildings, the unification of Rădăuţi with Volovăt in the southwest and a few less important tentacular extensions along secondary circulation channels in the north and north-east. The eastern part remains less dynamic, with EGGER's industrial unit being one of the factors that can explain the lack of attractiveness of the residential building area.

\section{The role of functional evolution in finishing the internal structure of Rădăuţi}

"Most often the city is distinguished by its particular functions related to an essential characteristic: power, as well as rare, varied activities tailored to numerous, demanding populations corresponding to specific societies." [15]

Rădăuţi has an internal structure that includes areas of lotizing with different functions: dwelling, agricultural, industrial units, public household units and utilities, waste disposal, tourist and recreational units, special destination units, as observed on the zoning functional map (Fig.2). [16]

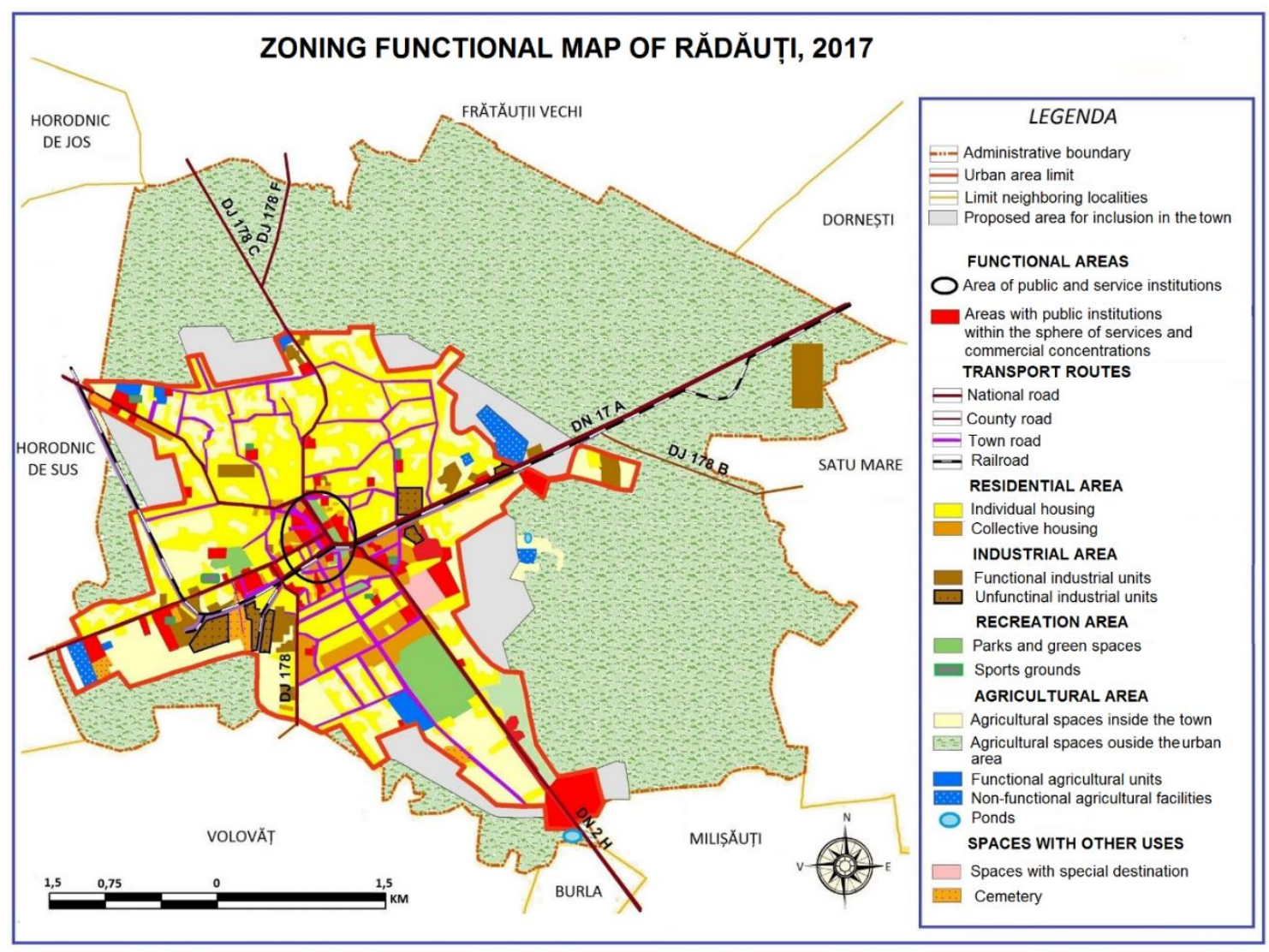

Figure 13. Zoning functional map of Rădăuți, 2017

The formation of functional areas took place in Rădăuţi in parallel with the territorial evolution of the settlement, this process was initially more the result of a spontaneous development in time, later in the socialist period and in the present period it had a directed character, as far as possible, a territorial systematization and a better service for the population. 
The historical center of the city is associated with land and buildings for public institutions and services located predominantly in the city center. In this central area are located, relatively compact areas representing the mixed functions with dwellings and services, service units, commercial activities, tourism, offices, banks. The structure of the central part is preserved from the period of formation of the trade-craft and administrative nucleus. Social and economic development at the end of the twentieth century and the beginnings of the 21st century led to the emergence in the central area of the city of many new institutions with an administrative, cultural and sanitary role, requiring the construction of more and more buildings special or adaptation of older, residential buildings of a larger size to the function of public institutions, schools or hospitals.

The central area, the narrowest of its surface, includes the historic center and overlaps the commercial-administrative core of the settlement. Today, this urban area concentrates the bulk of urban services, as a consequence of a sustained tertiary process carried out here after 1990. At the same time, it preserves its secondary function as a residential function, the space that encompasses in its physiognomy elements from all the historical periods analyzed. These are evident in the architectural style of the buildings as well as in the living space.

The most extensive functional area within the municipality is the residential one. On most of its surface it has an inherited structure since the 19-20th century, dominated by large spaces of individual (single and multi-family) dwellings with courtyards interposed among agricultural lands. On smaller surfaces, in the south and southwest of the city, collective housing has been built since 1965 to date. Residential dwellings with individual dwellings occupy the largest areas inside the settlement, the housing fund has a height of $\mathrm{P}+1$, less $\mathrm{P}+2$ (ground floor and 1,2 floors), and they also have the largest share of buildings. The residential area with collective housing (blocks) were built during the communist regime, especially in the south, southwest and central part of the city, the housing stock consists of blocks of flats $\mathrm{P}+4$ and houses with height regime $\mathrm{P}, \mathrm{P}+1$ and above rarely $\mathrm{P}+2$. Isolated blocks were generally built after 2005 on inland or outland surfaces and have a $\mathrm{GF}+4, \mathrm{P}+8$ height regime. By correlating the typology of dwellings with urban structure, we mention that the residential areas in the south of the city overlap with a rectangular, systemized structure, the straight streets close inside the geometric spaces occupied by blocks of flats, and in the rest of the city the morpostructure is unsystematic with winding, delimits spaces with various forms occupied by houses, orchards, gardens.

The traditional industrial area of the city began to emerge as early as the 19th century on the western outskirts of the city, favored by the existence of a railway station that facilitates the transportation of raw materials to existing factories in this area. Characterized by large and continuous expansion in the area, this area has embraced the main industrial units of the city, both in modern and contemporary times, especially in the socialist one. The construction of the spirit factory at the end of the 18th century, and later the railroad, led to the shaping of a new industrial area in the east of the city. Here, in the 20th century, a multi-section metalworking enterprise was also built. After 1990, these areas gradually changed their functional profile, large industrial units were closed, only the furniture factory continued its activity. In the eastern area, industrial sites have been redeveloped, replaced by warehouses of construction materials, commercial warehouses, and smaller units of construction and metallic assemblies. Outside the town of Dorneşti, the EGGER industrial platform was located. In the current internal structure of the city are included both spaces with functional industrial units (industrial production, 
warehousing, logistics, industrial services) as well as industrial relict spaces with nonfunctional units, inherited from the socialist period (some even older, for example the spirit factory). Nowadays, functional industrial production areas are present in the eastern administrative area of the city where the Egger Platform is expanding. The post-industrial landscape is characterized by the presence of smaller units that do not require, as in the past, an obvious industrial infrastructure, but have features that intertwine in the landscape of residential areas through a more or less modern look.

The transport area, mainly concentrated in the center and west of the city, is a larger road network with densities in the central area, taxiway spaces and car park spaces (located in the west of the city). The street network that provides transport services for people and goods across the city is represented by a network of roads with a level of differentiation and modernization. The main road access roads have a radial layout, being internally complemented by a dense road network that provides short-distance travel between the city's points of interest. The street network in the southern part of the railroad dividing the city into two is a regular one, with a rectangular configuration with better geometric elements, and the one on the northern side is spontaneous, with sinuous trails, with insufficient development of geometric elements in the plan, largely preserved from the past. A characteristic feature of the Rădăuți highway network, inherited from the past, is the separation of the north and the south from the railway, the connection between them being made by level crossings with the railway. [17]

The shopping area overlaps mainly the center of the city and extends on Stefan cel Mare Street, trading area being located both at the ground floor of the buildings (according to the structure modeling of the crafts trade center from the 19th century and the first half of the 20th century (the General Shop) or after 1990. The trading area serving the Hipodrom, Mihai Viteazul, Bogdan Vodă neighborhoods is imposed by a linear configuration, being represented by larger and smaller units located in the along the Mihai Viteazul street. Smaller concentrations are located in the main residential districts. A new shopping area is currently being set up, in the west of town, where the new supermarkets (Kaufland, Lidl) are located.

The green and recreational area is currently well-arranged and is based on an older structure that includes green spaces set up from the beginning of the 20th Century (Central Park), but also parks and house gardens or gardens within the neighborhoods arranged in different periods and green areas arranged on the alignment of the main streets. A defining element for the image of the city is the central park whose position has been preserved since the beginning of the 20th century.

The size of the city allows us to talk about the agricultural area, which is quite distinct from the city's landscape, with an insular extension in the northern region and more compact lands to the outskirts, especially to the south. It is worth mentioning that the area of this area has diminished a lot (from 2541ha in 1965 to 2134 ha in 2011) [18], while its place was taken by housing and various urban arrangements.

\section{CONCLUSIONS}

The overall focus on urban planning and the facilities that ensure the living and development of urban activities reveal that the current internal structure is the result of the city's evolution in time.

The spatial evolution of Rădăuţi was closely related to its economic and demographic development. was achieved through territorial continuity and internal densification. The way in which the territorial evolution has made its mark on the internal structure of the 
city is evidenced by: the current configuration of the street network, the form and the profile of the settlement, the urban image and how they are reflected in the current city image.

We can appreciate that the functionality of the territory played an essential role in the internal structure of the city. Human activities, through time development, have shaped the structure and functionality of the space. The multiplication of settlement functions over time has contributed to the internal organization of the city: spaces currently have different utilities are configured in different historical periods. Over time, some functional structures have disappeared others, through historical inertia, have been preserved in the structure and actual physiognomy of the settlement.

The shape of the city, as a result of its territorial and functional evolution, is circular, with a more prominent extension on the traffic axis connecting Rădăuţi and Suceava. The functional areas are generally arranged in the form of concentric circles that have a balanced weight: the central area preserves the historical specificity, the urban area has retained the dwelling function acquired since the 19th century. XIX-XX, but the new tertiary trend is evident and the external urban area is characterized by the loss of agricultural functionality in favor of residential and industrial function. On the whole, the city's evolution can be characterized as quite balanced. The city's hearth has maintained its location for centuries, tentacle-like expansions are characteristic of the current period. The transition to the market economy has been centered on a vast urban restructuring process that has attracted a new way of life. The restructuring process, which began in 1990, is already reflected in the internal structure of the city by modifying the functionality of spaces and by internal densification and reflect the differentiated integration of historical heritage into new trends in urban development .

\section{REFERENCES}

[1] Ianoş, I. Cities and Organization of Geographical Space. Study of Economic Geography on Romanian Territory, Academy Publishing House, Romania, pp.29, 1987.

[2] Ungureanu, Al. Cities in Podisul Moldovei. Economic geography study, Academy Publishing House, R.S. Romania, pp. 43-48, 1980.

[3] National Institute of Statistic, Land surface by mode of use, by counties and localities, available at http://statistici.insse.ro:8077/tempo-online/\#/pages/tables/insse-table, Romania, 2018.

[4] Iațu, C. Radauti Depression - Study of human geography, Corson Publishing House, pp. 310, 2002.

[5]Luchian, D. Rădăuți - Romanian hearth of socialist traditions and achievements, Publishing House Litera, pp.28, 1982.

[6] Cantemir, D., Descriptio antiqui et hodierni status Moldaviae, available online at https://bibliotecapemobil.ro/content/scoala/pdf/Descrierea_Moldovei_Dimitrie_Cantemir.pdf, pp.11, original text published in 1716.

[7] Luchian, D. Rădăuți - Romanian heart of socialist traditions and achievements, Publishing House Litera, pp.1-34, 1982.

[8] Drăguşanul, I.The story of Bucovina settlements, Muşatinii Publishing House, Suceava, available online at http://dragusanul.ro/category/povestea-asezarilor-bucovinene-i-si-ii/page/5

[9]Luchian, D. Rădăuți - Romanian hearth of socialist traditions and achievements, Publishing House Litera, pp.141, 1982. 
[10] Ungureanu, Al. Cities in Podisul Moldovei. Economic geography study, Academy Publishing House, R.S. Romania, pp. 43, 1980.

[11] Ungureanu, Al. Cities in Podisul Moldovei. Economic geography study, Academy Publishing House, R.S. Romania, pp. 45, 1980.

[12] Luchian, D. Rădăuți - Romanian hearth of socialist traditions and achievements, Publishing House Litera, pp.20, 1982.

[13] Ungureanu, Al. Cities in Podisul Moldovei. Economic geography study, Academy Publishing House, R.S. Romania, pp. 45, 1980.

[14] National Institute of Statistic. Stable population after domicile available online at http://statistici.insse.ro:8077/tempo-online/\#/pages/tables/insse-table, 2018.

[15] Istrate, Marinela. Urban Rural Relations in Moldova in the Contemporary Period, University „Al. I. Cuza” Publishing House, pp.36, 2008.

[16] General Urbanistic Plan of Rădăuți Municipality Suceava County, vol. I,

General Memorandum, realized by SC Habitat SA Iași, pp.172, 2008.

[17] General Urbanistic Plan of Rădăuți Municipality Suceava County, vol. I,

General Memorandum, realized by SC Habitat SA Iași, pp.166, 2008.

[18] National Institute of Statistic. at http://statistici.insse.ro:8077/tempoonline/\#/pages/tables/insse-table, 2011.

***The annual statistical reports of Suceava county from 1965 and 2011.

*** http://population.city/romania/radauti/ (accessed at 2 January 2019).

*** http://geoportal.ancpi.ro/ (accessed at 4 January 2019).

*** www.mapire.eu (accessed between 1-30 January 2019)

*** The Military Firing Plan, Rădăuți sheet, 1951, scale 1:20.000

*** The topographical plans from 1984, scale 1:25000.

*** Ortophotos from 2005, 2012

*** Aerial images of Rădăuți from Google Earth. 